\title{
An Evaluation of Flight Attendants' Safety Attitudes
}

\author{
Uçuş Görevlilerinin Emniyet Tutumlarına İlişkin Bir Değerlendirme
}

\author{
Sabiha ANNAÇ GÖV \\ Dr. Öğr. Üyesi, Gaziantep Üniversitesi, \\ Havacllı ve Uzay Bilimleri Fakültesi, \\ HavacılıkYönetimi Bölümü,sgov@gantep.edu.tr \\ https://orcid.org/0000-0001-7601-559X
}

Makale Başvuru Tarihi: 16.05.2021

Makale Kabul Tarihi: 19.08.2021

Makale Türü: Araştırma Makalesi

\author{
Nilay ERBAY \\ Yüksek Lisans Öğr., Gaziantep Üniversitesi, \\ S.B.E., Havacılık Yönetimi A.B.D., \\ erbaynilayerbay@gmail.com \\ https://orcid.org/0000-0002-6312-0662
}

\section{Anahtar Kelimeler: \\ Havacılık, \\ Havayolu, \\ Uçuş Görevlileri, \\ Emniyet Tutumlarl, \\ Türkiye,}

\section{Keywords:}

Aviation,

Airline,

Flight Attendants,

Safety Attitudes,

Turkey,

\section{ÖZET}

Emniyet tutumu, çalışanların emniyet politikaları ve önlemleri hakkındaki inançlarını ve duygularını yansıtır. Emniyet tutumlarl, çalışanların güvenlik davranışları üzerinde önemli bir etkiye sahiptir. Uçuş görevlileri uçus içi emniyet ve hizmetlerde hayati bir rol oynar. Ticari uçakları içeren ölümcül kazaların çoğunun, uçuş ekibi arasındaki iletişim ve ekip çalışmasındaki başarısızlıklardan kaynaklandığ çalışmanın amacı, uçuş güvenliği tutumlarında havayolu uçuş ekibinde kadın ve erkek arasında bir farklılaşma olup olmadığını ortaya çıkarmaktır. Çalışmada Ford ve dĭg. (2014) tarafindan geliştirilen Uçuş emniyet tutumu anketi kullanılmıştır. Bu çalışmada gönüllü olan 58 uçuş görevlisine anket uygulanmıştır. Uçuş güvenliği tutumlarındaki iki kategorik değişken arasındaki önemli farklılıklar, parametrik olmayan testlerden biri olan Mann-Whitney U testi kullanılarak analiz edilmiştir. Analiz sonuçlarına göre erkeklerin uçuş güvenliği tutumları, kadınların uçuş güvenliği tutumlarından daha yüksek olduğu tespit edilmiştir. Araştırma, emniyet tutumu konusunda Türkiye'de yapılan bir çalışma olması yönüyle literatüre katkı sağlayacaktır.

\section{ABSTRACT}

Safety attitude reflects employee beliefs and feelings about safety policies and measures. Safety attitudes have a significant influence on employee safety behaviour. Flight attendants play a vital role in in-flight safety and services. It is known that most fatal accidents involving commercial aircraft are caused by failures in communication and teamwork among flight attendants. This study aims to find out whether there is a differentiation between men and women in airline flight crew in-flight safety attitudes. In the study, the flight safety attitude questionnaire which was developed by Ford et al. (2014) was used. The questionnaire was applied to 58 volunteer flight attendants in the study. Significant differences between the two categorical variables in-flight safety attitudes were analysed using the Mann-Whitney $U$ test which is one of the nonparametric tests. According to the results of the analysis, it was determined that the flight safety attitudes of men were higher than the flight safety attitudes of women. The research will contribute to the literature as it is a study conducted in Turkey on safety attitudes. 


\section{INTRODUCTION}

Accident investigations' primary purpose is to decide the simple reasons and utilize the data obtained to prevent the accidents from occurring again. However, the same types of accidents continue to occur (Baron, 2012). Most of the fatal accidents involving commercial aircraft have been caused by the cabin and flight crew (Ford et al., 2014). For example, The Northwest Flight 255 (1987) and Delta Air Lines Flight 1141 (1988) accidents are caused by the violation of the sterile cockpit rule. The crew converse about non-flight-related subjects rather than executing the checklists of "taxi" and "take-off" by the Northwest pilots. In The Delta accident, the flight deck crew and a flight attendant who sit on the jump seat discussed the everyday routines of cabin crews. Mandala Airlines Flight 091 accident in 2005 and again, Spanair Flight 5022 accident in 2008 were caused by similar reasons (Baron, 2012). Another example from Turkey, TK 5904 (1999), crashed after take-off 8 minutes later. Accident investigations indicated that the cockpit was distracted by the presence of flight attendants in the cockpit and did not fulfill the checklist items (Mengenci, 2014).

The Helios Flight 522 (2005) crashed in the mountains close to Athena Airports, with 121 occupants (Brown and Rantz, 2010). In the cockpit, an intermittent aural warning horn was experienced by the crew; the aircraft was climbing through 16.000 feet (Aviation Safety Network, 2005; Tsolakis, 2006; Kiss, 2019). Despite the warning horn, the crew continued to climb because they believed indicated the take-off configuration warning. As the altitude of the inflight passed through 18.200 feet, the passenger oxygen masks deployed (Us airways, 2000; Kiss, 2019). The cockpit crew failed to understand the caution and soon became unconscious. The aircraft, which is on auto flight mode, continued to climb to a cruise altitude of 34.000 feet. It then descended and crashed after running out of fuel (Kiss, 2019). Therefore, the cabin attendants must have special/expert communication skills such as situational awareness, teamwork, leadership, and decision-making in such cases (International Civil Aviation Organization, 2014).

The instruction of Turkey Civil Aviation, cabin attendants, must be trained on the authority and responsibility in implementing emergency procedures (Kabin Personeli Eğitimi ve Standardizasyonu, 2002). In decompression, flight attendants follow communication procedures after putting on the oxygen mask by securing themselves and occupying the closest seat. If available, this seat must be at a safe location. Communication procedures may include communicating with the flight crew in the case of a slow decompression to make sure of their awareness of the situation and, confirm that they have already put on their oxygen masks (International Civil Aviation Organization, 2014).

Dryden accident (Moshansky, 1992; Ford et al., 2014) and Kegworth accident (Air Accidents Investigation Branch, 1990; Ford and et al., 2014) indicated serious mistakes in communication and teamwork between the pilots and flight attendants (Ford et al., 2014). Helmreich et al. (1999) has identified that joint training might improve flight attendants' accident/safety management process. The aviation industry developed a joint CRM training including flights attendants to improve team coordination and communication. This is within each group and between the groups (Ford et al., 2014).

This study aims to determine whether there is a significant difference between the perceptions of women cabin crew and men cabin crew on flight safety attitudes. Firstly, for this paper, the conceptual framework was examined, and an online survey was conducted to evaluate the attitudes of different gender flight attendants on safety. As seen in aviation management literature and scale used (original questionnaire) "cabin crew" and "flight attendant" and also "flight deck" concepts are used synonyms. Therefore all of them are used in the study.

\section{CONCEPTUAL FRAMEWORK}

One of the most critical points in aviation safety is training programs that were approved and implemented widely by aiming at effective teamwork and cockpit crew management in the last ten years. Cockpit resource management was the first version of the training, the concept of Crew Resource Management (CRM) has to turn into general use including, other aviation community members such as flight attendants, dispatchers, and maintenance staff. CRM has changed its scope from cockpit to crew in a short while as the changing human factors over time (Heilmreich and Foushess, 2010).

CRM was defined as "a way to train aircrew to use all available resources (equipment, people and information) by communicating and coordinating as a team" (Salas et al., 2001). It is designed to increase air crews' 
efficiency and reduce failures (Wiener et al., 1993; Marron, 2018). The aviation industry experienced an increasing number of accidents caused by poor teamwork and decision-making. The importance of communication among and between the aircrew groups increased, as aircraft complexity increased (Jimenes et al., 2015).

Safety attitude reflects employee beliefs and feelings about safety policies and measures (Henning et al., 2009). Safety attitude is composed of four parts, namely safety hardware and physical hazards, safety software and concepts, people, and risk (Cox and Cox, 1991). Within the airline industry, as a frontline service employee, a flight attendant plays a vital role in taking charge of the information conveyed to the flight crew, and in shaping key customer outcomes (Chang and Chiu, 2009). Flight attendants with a poor safety attitude cannot implement airline rules related to safety compliance and safety participation, and they cannot be mindful of safety practices. These attendants are unable to handle their duties efficiently and effectively, which could lead to communication barriers between the crew, as well as service failures, and thus flight risk and customer defections (Gabbott et al., 2011).

The International Civil Aviation Organisation (ICAO) defines safety as identifying hazards and risks in the event of damage to persons or property, reducing or keeping these risks below an acceptable level through safety risk management systems . The development process of the concept of safety in the aviation sector has brought with it applications such as CRM to ensure and increase safety in aviation operations (Yelgin and Ergün, 2020) Being the frontline operators in the airline industry, flight attendants constantly obtain and collect first-hand information from their interactions with passengers and other crew members. Their experiences and observations may contribute greatly to airlines' safety management and policymaking.

\section{LITERATURE REVIEW}

In aviation, accidents have been caused by human error in most of the case. The possibility of human error accidents ranges from \%60 to \%80 (Freeman and Simmon, 1991; Salas et al., 2001). Cabin attendants play an important role in the safety of flight and other services. Since the behaviors of cabin crews' safety are important to the overall performance of an airline's safety, they deserve special consideration (Kao et al., 2009; Chen and Chen, 2013).

Murphy (2001) indicates that cabin attendants are in a dilemma of knowing when to do or break their daily inflight routines by risking the sanctions of an organization and/or interpersonal. Murhphy conducts a qualitative study on the feminized cabin crew role and its contribution to the air travel performance that is seen as dominant. In this study, there are examples of incidents that affect the performance of dominant air travel, leading the flight attendant to face a dilemma. For this study, the researcher conducted interviews with cabin crews during the flights alongside NWA (National World Airways). So, these interviews were not paid for by the company or himself. Data for the paper were collected from over 40 flight attendants who volunteered in the research, including 29 Caucasian women, 4 Caucasian Men, 6 African-American women, and 1 AfricanAmerican man (Murphy, 2001).

Ford and O'Hare (2013) investigated a manipulation's effectiveness derived from the "social categorization and social identity" theory to support more cabin attendant willingness in terms of intergroup communication and teamwork in airline operations. The study concludes that the attitudes towards teamwork and communication can be enhanced by priming social identity, potentially leading to take an interest to participate in intergroup cooperation. It indicates that the "social categorization and social identity" theory can be used to contribute to joint training program development to adopt effective communication and teamwork behaviors by increasing the willingness of the flight attendants and pilots. Social categorization and social identity provide a way of understanding how two very different subgroups separated by power and status could become more willing to engage in positive intergroup behaviors. Social identity and social categorization theories suggest that priming a sense of social identity would lead to a greater willingness to engage in intergroup cooperation.

The effectiveness of CRM training for flight attendants or joint groups consisted of both flight attendants and pilots was not commonly studied. There are many studies on the effectiveness of CRM training for only flight crew (Salas et al., 2001; Ford et al., 2014).

Ford et al. (2014) filled this gap by primarily developing and testing a self-report tool to measure flight attendants' safety attitudes. Secondly, at a major airline, they conducted a survey two times before and after training to evaluate the effectiveness of CRM training that was newly developed for flight attendants. In this paper, the self-report tool has given the name of FSAQ (Flight Safety Attitudes Questionnaire) that is mixed 
with earlier questionnaires (Helmreich, 1984; Gregorich et al., 1990; Ford et al., 2014; Helmreich et al., 1993; Ford et al., 2014). In conclusion, this study shows that a new tool (FSAQ) is highly suited to discover the safety attitudes of flight attendants. Besides this, CRM training is effective for flight attendants, and the perception of cabin crews' flight safety attitudes increases after training (Ford et al., 2014).

This paper revealed that the impact of job demands and job resources is crucial to flight attendants' safety attitudes. Chen and Chen (2014) studied cabin crew's safety behaviors and aimed to determine the effects of job demand and resources on it. They evaluated the job demands as emotional demands and workload. Job resources referred to the nature and development of a job that is related to the job characteristics of the cabin crew. Job characteristics were discriminated into three types of safety behaviors such as in-role, extra-role, and upward safety communication. They concluded that the job demands might create negative effects on in-role safety behavior, extra-role safety behavior, and upward safety communication and job resources positively support these three job characteristics. Cabin crews' behavior is antecedent to cabin attendants' extra-role safety behavior and upward safety communication. Moreover, flight attendants who have a higher perception of having job resources consider that job demands are not effective on their job characteristics (Chen and Chen, 2014).

Chen (2017) researched flight attendants working for Taiwanese international airlines. The cabin crew department managers' paternalistic leadership style is adopted to observe how it may trigger cabin crews' different types of voice behavior. This research addresses the following two major issues: Motivation factors for cabin crew to conduct upward safety communication and how department managers' paternalistic leadership style impacts cabin crew's voice behavior. This study finds that deputy pursers perform voice behavior because of resignation or disengagement rather than altruism. This is something that requires immediate attention since deputy pursers are in a position that supports all cabin work.

Ji et al. (2019) investigated the orientation of flight attendants' safety behavior according to their high level of safety awareness. They indicated that promptly judging and reporting potential hazards is a critical element of a flight attendant's safety, more so than of the orientation of their organizational behavior. This means that the practices of safe working were promoted to alert colleagues or break the operations if the safety conditions are unclear. Thus, some undesirable and unexpected events can be stopped or prevented (Aesa et al., 2005; Skjerve, 2008; Ji et al., 2019). In conclusion, this paper reveals that proactive personality doesn't predict cabin attendants' safety behaviour. However, safety attitude is a mediator between proactive personality and safety behaviour. Proactive personality positively predicts flight attendants' safety attitude and safety attitude also predicts flight safety behaviours.

Yelgin and Ergün (2020) researched the job demands perceived by cabin crew members. The job demands perceived by the cabin crew were classified under three themes as key responsibilities, passenger demands, and individual elements. Key responsibilities involve the application of the procedures of the cabin crew profession related to safety and in-cabin services, dealing with operational problems in-flight processes, observing safety and passenger satisfaction and reporting safety risks, adapting to teamwork, and fulfilling the responsibilities assigned to the division of labour, and making the necessary sacrifices in representing the airline. Passenger Demands theme includes the demands created by the workload due to the flight inexperience of the passengers on board during the flight and the demands for the provision of catering services for the airline on the flight route. Also, this theme subsumes the business demands that involve dealing with passengers who engage in rude behaviour and communicating effectively with passengers during the flight process. Individual Factors theme comprises having the personality appropriate to the job characteristics of the flight attendance profession, meeting the demands of the profession requiring different lifestyle, being able to achieve work-life balance as required by the working conditions, and also the job demands related to the individual factors that the employee must have physically, mentally and emotionally.

\section{METHOD}

\subsection{The Subject, Purpose and Importance of the Research}

The subject of the study is the safety attitudes of cabin crew or flight attendants. The purpose of the study is to determine whether there is a significant difference between the perceptions of women cabin crew and men cabin crew on the flight safety attitudes. Firstly for this paper, the conceptual framework was examined, and an online survey was conducted to evaluate the attitudes of different gender flight attendants on safety.

Gerede (2006) defined the concept of aviation safety like this. All aviation activities; In real-life conditions, all known risk factors; occurring at an acceptable level of risk that is demonstrated and avoided. Safety is essential 
for the aviation industry. Undoubtedly, the first sentence heard by an employee who stepped into the aviation industry is: aviation history was written in blood. Attacks that may sabotage aviation operational activities and the consequences of accidents during operation activities undoubtedly support this sentence. Because of these reasons topic of the study is important.

\subsection{Research Model and Hypotheses}

Judicial sampling is an inexpensive, convenient, and fast method. It is not directly generalized to a particular population because the population cannot clearly define it. Judgment sampling is subjective, and its values are based entirely on the researcher's judgment, expertise, and creativity. This sampling is used in situations that do not require inference from a large population. Non-Probability (Judicial) Sampling Selection Techniques can be used in situations where a social institution, group, or small social system is investigated. Therefore, it makes no sense to choose a sample from the universe. In other words, in some cases, the research results are not intended to be generalized to a larger universe. It is used for non-probabilistic sampling types where generalization to the population is not important. This type of sampling requires them to have some characteristic features within their body rather than the rule of choosing units objectively (Balc1, 2001:52-117). The more homogenous the central mass is and the better the researcher knows about it, the better the sample determined by this method will yield. However, since the representative power of the sample selected by the judicial sampling method is not known, it becomes more difficult to generalize about the population (Malhotra, 1996). Generally, the acceptability of the sample size varies depending on the type of research. Thirty participants are recommended for causal-comparative and most experimental studies. If the sample is too small, research the results may not be generalized to the population. The results can only be taken into account for the sample (Özen and Gül, 2010). Based on the literature, the research hypothesis is determined as follows.

\section{H1: There is no difference between the safety attitude-behavior perceptions of female and male cabin workers.}

\subsection{The Sample and Limitations of the Study}

The online surveys were sent to WhatsApp groups that consisted of flight attendants working at a major airline company in Turkey and created for initial flight training and recurrent. Sixty flight attendants were reached and 58 of them participated as a volunteer in Turkey. The limitation of the study is that the example is small and cannot be generalized to the universe. Like any non-parametric test, the Mann-Whitney $U$ does not depend on assumptions on the distribution. One does not need to postulate the data distribution of the target population. One can also use it when the conditions of normality neither are met nor realizable by transformations (Nachar,2008).

\subsection{Data Collection Method of the Study}

The 33 items from the FSAQ (Flight Safety Attitudes Questionnaire) (Ford et al., 2014) were applied to Turkey's flight attendants' job rules in Turkey. An online survey was prepared. The survey questions were fivepoint Likert scale that ranged from "strongly disagree" to "strongly agree". The online surveys were sent to WhatsApp groups that consisted of flight attendants working at a major airline in Turkey and created for initial flight training and recurrent. 60 flight attendants were reached and 58 of them participated as a volunteer. The others didn't want to participate. 58 participants are enough for comparing gender's safety attitudes. No study has been found on this subject in Turkey. Statistical analysis was carried out despite the small number of participants, as it was considered to form the basis of the studies to be carried out. Mann-Whitney U test was used due to the low number of participants (Mann and Whitney, 1947). This test is used safely when the number of participants is small. Therefore this sample can be enough for the study. Therefore, nonparametric tests are also called distribution-free. This test has the great advantage of possibly being used for small samples of subjects such as five to 20 participants. It can also be used when the measured variables are of an ordinal type and were recorded with an arbitrary and not a very precise scale (Nachar, 2008). 


\subsection{Data Analysis Methods and Reliability of the Study}

Mann-Whitney U test from non-parametric tests was conducted in this study. In the light of the data collected, it was tested whether the flight safety attitudes differ according to gender. Mann-Whitney U test is one of the most widely used nonparametric tests to test the significance of the difference between two independent groups. This test determines whether two independent groups come from the same population or two different populations with the same average. In other words, by comparing the measurements of two independent groups of samples for a dependent variable, it is tested whether there is a significant difference between the two distributions. The Mann-Whitney test is used instead of the independent samples t-test (a parametric test) when the data are not parametric (Gürbüz and Şahin, 2018). The reliability of the questionnaire was made by Ford et al. (2014).

\section{FINDINGS}

Sixty flight attendants were reached from the sample determined within the scope of the study, and when the online survey was administered, the scale was returned by 58 of those contacted. As we look at the demographic characteristics of the participants, this consists of 34 women and 24 men, 4 pursers, 4 cabin chiefs, and 50 cabin attendants. According to the experience years of the participants, there are 8 flight attendants (15 and over the years experience), 14 flight attendants (5-9 years experience), and 36 flight attendants ( $0-4$ years experience). Mann-Whitney $\mathrm{U}$ test analysis shows that there are no significant differences in-flight safety attitudes between women and men.

Table 1. Mann-Whitney U Test

\begin{tabular}{|c|c|c|c|c|}
\hline FSAQ items & GENDER & $\mathbf{N}$ & $\begin{array}{l}\text { MEAN } \\
\text { RANK }\end{array}$ & $\begin{array}{r}\text { SUM OF } \\
\text { RANKS }\end{array}$ \\
\hline $\begin{array}{l}\text { "1. Pilots see the flight attendants as valuable contributors } \\
\text { to flight safety" }\end{array}$ & $\begin{array}{c}\text { Woman } \\
\text { Man } \\
\text { Total }\end{array}$ & $\begin{array}{l}34 \\
24 \\
58 \\
\end{array}$ & $\begin{array}{c}31,06 \\
28,5\end{array}$ & $\begin{array}{l}528 \\
342\end{array}$ \\
\hline $\begin{array}{l}\text { "2. I am encouraged by other flight attendants to report } \\
\text { any unsafe conditions" }\end{array}$ & $\begin{array}{c}\text { Woman } \\
\text { Man } \\
\text { Total }\end{array}$ & $\begin{array}{l}34 \\
24 \\
58\end{array}$ & $\begin{array}{l}26,36 \\
35,16\end{array}$ & $\begin{array}{l}448 \\
422\end{array}$ \\
\hline $\begin{array}{l}\text { "3. Pilots notify the flight attendants about unusual } \\
\text { situations" }\end{array}$ & $\begin{array}{c}\text { Woman } \\
\text { Man } \\
\text { Total }\end{array}$ & $\begin{array}{l}34 \\
24 \\
58\end{array}$ & $\begin{array}{l}29,58 \\
30,58\end{array}$ & $\begin{array}{l}503 \\
367\end{array}$ \\
\hline $\begin{array}{l}\text { "4. I know enough aircraft terms to describe a safety } \\
\text { concern to the pilots" }\end{array}$ & $\begin{array}{c}\text { Woman } \\
\text { Man } \\
\text { Total }\end{array}$ & $\begin{array}{l}34 \\
24 \\
58\end{array}$ & $\begin{array}{c}26,7 \\
34,66\end{array}$ & $\begin{array}{l}454 \\
416\end{array}$ \\
\hline $\begin{array}{l}\text { "5. I am confident about reporting cabin condition } \\
\text { defects" }\end{array}$ & $\begin{array}{c}\text { Woman } \\
\text { Man } \\
\text { Total }\end{array}$ & $\begin{array}{l}34 \\
24 \\
58\end{array}$ & $\begin{array}{l}26,76 \\
34,58\end{array}$ & $\begin{array}{l}455 \\
415\end{array}$ \\
\hline $\begin{array}{l}\text { "6. Pilots encourage cabin crew to voice their safety } \\
\text { concerns" }\end{array}$ & $\begin{array}{c}\text { Woman } \\
\text { Man } \\
\text { Total }\end{array}$ & $\begin{array}{l}34 \\
24 \\
58\end{array}$ & $\begin{array}{l}29,76 \\
30,34\end{array}$ & $\begin{array}{l}506 \\
364\end{array}$ \\
\hline "7. I think (the airline) has a positive safety culture" & $\begin{array}{c}\text { Woman } \\
\text { Man } \\
\text { Total } \\
\end{array}$ & $\begin{array}{l}34 \\
24 \\
58 \\
\end{array}$ & $\begin{array}{l}29,88 \\
30,16\end{array}$ & $\begin{array}{l}508 \\
362\end{array}$ \\
\hline $\begin{array}{l}\text { "8. Pilots and flight attendants work together effectively } \\
\text { at (the airline)" }\end{array}$ & $\begin{array}{c}\text { Woman } \\
\text { Man } \\
\text { Total }\end{array}$ & $\begin{array}{l}34 \\
24 \\
58 \\
\end{array}$ & $\begin{array}{l}31,88 \\
27,34\end{array}$ & $\begin{array}{l}542 \\
328\end{array}$ \\
\hline $\begin{array}{l}\text { "9. Using the Security Search Check List facilitates team } \\
\text { coordination" }\end{array}$ & $\begin{array}{c}\text { Woman } \\
\text { Man } \\
\text { Total }\end{array}$ & $\begin{array}{l}34 \\
24 \\
58\end{array}$ & $\begin{array}{l}25,24 \\
36,76\end{array}$ & $\begin{array}{l}429 \\
441\end{array}$ \\
\hline $\begin{array}{l}\text { "10. I have a good understanding of the flight deck's } \\
\text { responsibilities and role" }\end{array}$ & $\begin{array}{c}\text { Woman } \\
\text { Man } \\
\text { Total }\end{array}$ & $\begin{array}{l}34 \\
24 \\
58\end{array}$ & $\begin{array}{l}26,76 \\
34,58\end{array}$ & $\begin{array}{l}455 \\
415\end{array}$ \\
\hline $\begin{array}{l}\text { "11. Initial flight attendant training is relevant and } \\
\text { prepares crew for flying duties" }\end{array}$ & $\begin{array}{c}\text { Woman } \\
\text { Man } \\
\text { Total }\end{array}$ & $\begin{array}{l}34 \\
24 \\
58 \\
\end{array}$ & $\begin{array}{l}33,58 \\
24,92\end{array}$ & $\begin{array}{l}571 \\
299\end{array}$ \\
\hline $\begin{array}{l}\text { "12. Pre-flight safety checks are performed every time I } \\
\text { step onto a new aircraft" }\end{array}$ & $\begin{array}{c}\text { Woman } \\
\text { Man } \\
\text { Total }\end{array}$ & $\begin{array}{l}34 \\
24 \\
58\end{array}$ & $\begin{array}{l}30 \\
30\end{array}$ & $\begin{array}{l}510 \\
360\end{array}$ \\
\hline
\end{tabular}


ANNAÇ GÖV, Sabiha ve ERBAY, Nilay - An Evaluation of Flight Attendants' Safety Attitudes

\begin{tabular}{|c|c|c|c|c|}
\hline $\begin{array}{l}\text { "13. Pilots have a good understanding of the flight } \\
\text { attendant's job." }\end{array}$ & $\begin{array}{c}\text { Woman } \\
\text { Man } \\
\text { Total }\end{array}$ & $\begin{array}{l}34 \\
24 \\
58 \\
\end{array}$ & $\begin{array}{l}27,64 \\
33,34\end{array}$ & $\begin{array}{l}470 \\
400\end{array}$ \\
\hline $\begin{array}{l}\text { "14. All Purser/Cabin Chief pre-flight briefings are } \\
\text { relevant and thorough" }\end{array}$ & $\begin{array}{c}\text { Woman } \\
\text { Man } \\
\text { Total } \\
\end{array}$ & $\begin{array}{l}34 \\
24 \\
58 \\
\end{array}$ & $\begin{array}{l}24,58 \\
37,66\end{array}$ & $\begin{array}{l}418 \\
452\end{array}$ \\
\hline $\begin{array}{l}\text { "15. I am confident in my ability to properly assess } \\
\text { potential hazards to safety" }\end{array}$ & $\begin{array}{c}\text { Woman } \\
\text { Man } \\
\text { Total }\end{array}$ & $\begin{array}{l}34 \\
24 \\
58\end{array}$ & $\begin{array}{l}30,18 \\
29,76\end{array}$ & $\begin{array}{l}513 \\
357\end{array}$ \\
\hline "16. I understand the need for sterile cockpit procedures" & $\begin{array}{c}\text { Woman } \\
\text { Man } \\
\text { Total } \\
\end{array}$ & $\begin{array}{l}34 \\
24 \\
58 \\
\end{array}$ & $\begin{array}{c}30,3 \\
29,58\end{array}$ & $\begin{array}{l}515 \\
355\end{array}$ \\
\hline $\begin{array}{l}\text { "17. Pursers/Cabin Chiefs actively contribute to } \\
\text { teamwork on every flight" }\end{array}$ & $\begin{array}{c}\text { Woman } \\
\text { Man } \\
\text { Total } \\
\end{array}$ & $\begin{array}{l}34 \\
24 \\
58 \\
\end{array}$ & $\begin{array}{l}29,88 \\
30,16\end{array}$ & $\begin{array}{l}508 \\
362\end{array}$ \\
\hline $\begin{array}{l}\text { "18. I receive a pre-flight operational briefing from the } \\
\text { captain on every flight" }\end{array}$ & $\begin{array}{c}\text { Woman } \\
\text { Man } \\
\text { Total }\end{array}$ & $\begin{array}{l}34 \\
24 \\
58\end{array}$ & $\begin{array}{l}30,88 \\
28,76\end{array}$ & $\begin{array}{l}525 \\
345\end{array}$ \\
\hline $\begin{array}{l}\text { "19. I do not compromise safety for on-time } \\
\text { performance" }\end{array}$ & $\begin{array}{c}\text { Woman } \\
\text { Man } \\
\text { Total } \\
\end{array}$ & $\begin{array}{l}34 \\
24 \\
58 \\
\end{array}$ & $\begin{array}{l}28,36 \\
32,34\end{array}$ & $\begin{array}{l}482 \\
388\end{array}$ \\
\hline $\begin{array}{l}\text { "20. Crewmembers should not question the decisions or } \\
\text { actions of the captain except when they affect the } \\
\text { safety of the flight" }\end{array}$ & $\begin{array}{c}\text { Woman } \\
\text { Man } \\
\text { Total }\end{array}$ & $\begin{array}{l}34 \\
24 \\
58\end{array}$ & $\begin{array}{l}27,76 \\
33,16\end{array}$ & $\begin{array}{l}472 \\
398\end{array}$ \\
\hline $\begin{array}{l}\text { "21. Passenger concerns about abnormal situations are } \\
\text { always taken seriously by the crew i.e. odd noises, } \\
\text { smells, and anything out of the ordinary" }\end{array}$ & $\begin{array}{c}\text { Woman } \\
\text { Man } \\
\text { Total } \\
\end{array}$ & $\begin{array}{l}34 \\
24 \\
58 \\
\end{array}$ & $\begin{array}{l}30,18 \\
29,76\end{array}$ & $\begin{array}{l}513 \\
357\end{array}$ \\
\hline $\begin{array}{l}\text { "22. If I am unclear about something, I am not } \\
\text { embarrassed to speak up" }\end{array}$ & $\begin{array}{c}\text { Woman } \\
\text { Man } \\
\text { Total }\end{array}$ & $\begin{array}{l}34 \\
24 \\
58\end{array}$ & $\begin{array}{c}30 \\
30 \\
0\end{array}$ & $\begin{array}{c}510 \\
360 \\
0\end{array}$ \\
\hline $\begin{array}{l}\text { "23. Pursers/Cabin Chiefs who encourage suggestions } \\
\text { from crewmembers are weak leaders" }\end{array}$ & $\begin{array}{c}\text { Woman } \\
\text { Man } \\
\text { Total }\end{array}$ & $\begin{array}{l}34 \\
24 \\
58 \\
\end{array}$ & $\begin{array}{c}30,3 \\
29,58\end{array}$ & $\begin{array}{l}515 \\
355\end{array}$ \\
\hline $\begin{array}{l}\text { "24. Crewmembers should monitor each other for signs of } \\
\text { stress and fatigue" }\end{array}$ & $\begin{array}{c}\text { Woman } \\
\text { Man } \\
\text { Total }\end{array}$ & $\begin{array}{l}34 \\
24 \\
58 \\
\end{array}$ & $\begin{array}{l}34,06 \\
24,26\end{array}$ & $\begin{array}{l}579 \\
291\end{array}$ \\
\hline $\begin{array}{l}\text { "25. I appreciate the high workload times within the flight } \\
\text { deck" }\end{array}$ & $\begin{array}{c}\text { Woman } \\
\text { Man } \\
\text { Total }\end{array}$ & $\begin{array}{l}34 \\
24 \\
58\end{array}$ & $\begin{array}{c}32,12 \\
27\end{array}$ & $\begin{array}{l}546 \\
324\end{array}$ \\
\hline $\begin{array}{l}\text { "26. Good communication and crew coordination are } \\
\text { important for flight safety" }\end{array}$ & $\begin{array}{c}\text { Woman } \\
\text { Man } \\
\text { Total }\end{array}$ & $\begin{array}{l}34 \\
24 \\
58 \\
\end{array}$ & $\begin{array}{l}30 \\
30\end{array}$ & $\begin{array}{l}510 \\
360\end{array}$ \\
\hline $\begin{array}{l}\text { "27. I get total operational support from my FA team on } \\
\text { every flight" }\end{array}$ & $\begin{array}{c}\text { Woman } \\
\text { Man } \\
\text { Total } \\
\end{array}$ & $\begin{array}{l}34 \\
24 \\
58 \\
\end{array}$ & $\begin{array}{c}26,12 \\
35,5\end{array}$ & $\begin{array}{l}444 \\
426\end{array}$ \\
\hline $\begin{array}{l}\text { "28. Casuals and temporary cabin crew always feel part of } \\
\text { crew team" }\end{array}$ & $\begin{array}{c}\text { Woman } \\
\text { Man } \\
\text { Total }\end{array}$ & $\begin{array}{l}34 \\
24 \\
58\end{array}$ & $\begin{array}{l}27,42 \\
33,66\end{array}$ & $\begin{array}{l}466 \\
404\end{array}$ \\
\hline $\begin{array}{l}\text { "29. In abnormal situations, I rely on my superiors to tell } \\
\text { me what to do" }\end{array}$ & $\begin{array}{c}\text { Woman } \\
\text { Man } \\
\text { Total } \\
\end{array}$ & $\begin{array}{l}34 \\
24 \\
58 \\
\end{array}$ & $\begin{array}{c}28,24 \\
32,5\end{array}$ & $\begin{array}{l}480 \\
390\end{array}$ \\
\hline $\begin{array}{l}\text { "30. Pilots always understand the time constraints } \\
\text { governing service delivery" }\end{array}$ & $\begin{array}{c}\text { Woman } \\
\text { Man } \\
\text { Total }\end{array}$ & $\begin{array}{l}34 \\
24 \\
58\end{array}$ & $\begin{array}{l}29,48 \\
30,76\end{array}$ & $\begin{array}{l}501 \\
369\end{array}$ \\
\hline $\begin{array}{l}\text { "31. I tell crewmembers when my workload is becoming } \\
\text { excessive" }\end{array}$ & $\begin{array}{c}\text { Woman } \\
\text { Man } \\
\text { Total } \\
\end{array}$ & $\begin{array}{l}34 \\
24 \\
58 \\
\end{array}$ & $\begin{array}{c}25,06 \\
37\end{array}$ & $\begin{array}{l}426 \\
444\end{array}$ \\
\hline $\begin{array}{l}\text { "32. I have confidence in the leadership abilities of my } \\
\text { Purser/Cabin Chief" }\end{array}$ & $\begin{array}{c}\text { Woman } \\
\text { Man } \\
\text { Total }\end{array}$ & $\begin{array}{l}34 \\
24 \\
58\end{array}$ & $\begin{array}{c}27,7 \\
33,26\end{array}$ & $\begin{array}{l}471 \\
399\end{array}$ \\
\hline
\end{tabular}

As seen above in Table 1, the flight safety attitudes questionnaire is given in detail which was analyzed by using the Mann-Whitney $U$ test. As it is seen on the table, the mean rank levels of men participants are generally higher than women participants. 
Table 2. Descriptive Statistics

\begin{tabular}{|c|c|c|c|c|c|}
\hline & $\mathrm{N}$ & Mean & Std. Deviation & Minimum & Maximum \\
\hline FSAQ & 58 & 4,3302 & 0,36868 & 3,76 & 5,00 \\
\hline GENDER & 58 & 1,4138 & 0,50123 & 1,00 & 2,00 \\
\hline
\end{tabular}

As seen above Table 2 Descriptive statistics, the mean of flight safety attitudes scores is min=3,76 and Max=5,00. As it is seen on the table, the mean is 4,3302 so it can be said that rank levels of all participants are high enough for the safety attitudes of the flight crew.

\subsection{Hypothesis Tests and Results of the Research}

According to Mann Whitney U Test Results (Table 3), it is possible to say that the mean rank of man participants is higher than the mean rank of women participants.

Table 3. Mann-Whitney U Test Results

\begin{tabular}{|c|c|c|c|c|}
\hline & Gender & N & Mean Rank & Sum of Ranks \\
\hline \multirow{3}{*}{ FSAQ } & Woman & 34 & 27,48 & 467,00 \\
\cline { 2 - 5 } & Man & 24 & 33,58 & 403,00 \\
\cline { 2 - 5 } & Total & 58 & & \\
\hline
\end{tabular}

However, according to Table 4 asymp sig value $(, 339)$, this result shows no difference in safety attitude between men and women.

Table 4. Test Statistics

\begin{tabular}{|c|c|}
\hline & FSAQ \\
\hline Mann-Whitney U & 160,500 \\
\hline Wilcoxon W & 467,000 \\
\hline Z & $-0,957$ \\
\hline Asymp. Sig. (2-tailed) & 0,339 \\
\hline Exact Sig. [2*(1-tailed Sig.)] & $0,347^{\mathrm{a}}$ \\
\hline
\end{tabular}

a. Not corrected for ties.

b. Grouping Variable: GENDER

The significance (Assymp. Sig. $=0,339$ ) line in Table 4 is higher than 0.05 , which is accepted as the limit value in statistical significance calculations, showing that there is no significant difference between the observed values. If this value was less than 0.05 , it would indicate that the observed values differ significantly for the two groups (Gürbüz and Şahin, 2018).

The flight safety attitudes of women and men are $(M=4.33)$ and its standard deviation $(\mathrm{SD}=0.36)$. The findings show no significant difference between male and female flight safety attitudes $(U=160.500, p>0.05)$. According to the calculated rank average values, it is seen that the flight safety attitudes of men $(\mathrm{M}=33.58)$ are higher than the flight safety attitudes of women $(\mathrm{M}=27.48)$. However, the two categorical variables are not significantly different from each other. So "There is no difference between the safety attitude-behavior perceptions of female and male flight attendants. The hypothesis was accepted.

\section{CONCLUSION}

Flight attendants who might also be called 'air hostesses' or 'sky girls' were modeled as homemakers in the air. Airlines used their corporate image as a marketing element that an elegant hostess would take off the businessman's shoes, recline his seat, and provide food and drink to make him feel the warmth and comfort of his own home. The flight attendants are required as an air travel ritual that they constantly manage the tension between opposite roles at the same time: reassurance and safety, accommodation and authority. In other words, the role of feminine presence and the denial of death must be visibly performed by flight attendants (Murphy, 2001). 
Murphy (2001) indicates in the study that the feminized cabin attendant role affects the performance of dominant air travel and the existing inflight routines may be interrupted by the passenger's actions. Murphy makes quotes one of the interviewees in this paper. Sherri (one of the flight attendants interviewed) shared her memory of a young man who boarded her flight from Seattle to Salt Lake. When the passenger misunderstood the standard announcement about landing in Salt Lake, he started to scream at the top of his lungs. He thought they would land at Lake. In this case, the flight attendant was named. Indeed, she masked her authority by drawing on embedded, feminine communicative resources like a mother that tries to relax her child; she calmed the passenger who interrupted the flight safety. According to the researcher, Sherri solved the issue without using feminine performance to relax passengers (Murphy, 2001). As seen in Murphy's study, the cabin attendant role is essential. Murphy likened flight attendants such as a mother. Therefore he feminized the cabin attendant role. Unlike Murphy's study, our paper revealed that flight safety behaviours are not significantly different according to gender. Therefore our study emphasizes the importance of safety attitude and flight attendant's behaviours.

Punch (2011) states that there are two types of case studies. Firstly, the aim is to understand the event in its context and not generalize the problems (Punch, 2011; Şahin and Gürbüz, 2018). Stake (1995) stated that this kind of research is a true case study. Secondly, dealing with negative events which have unusual situations handled and finally, the purpose of these studies is to understand why those events differ. For instance, Stake (1995) described these studies as instrumental case studies (Stake, 1995; Şahin and Gürbüz, 2018).

Furthermore, Ji et al. (2019) concluded that safety attitudes predict safety behaviour. They are used in the FSAQ questionnaire to measure the safety attitude. According to this study, proactive personality positively predicts flight attendants' safety attitude but does not directly predict safety behaviour. In the light of this study, those with high safety attitudes are expected to have high safety behaviours.

In this research, it can be seen that the flight safety attitudes of men $(M=33.58)$ are higher than the flight safety attitudes of women $(M=27.48)$ according to the calculated rank average values, However, the two categorical variables are not significantly differing from each other. Thus, a calming role might be expected from the female flight attendant during interrupted routines for in-flight safety may not be adequate to explain the core of the issue. This paper revealed that the flight safety attitudes that predict flight safety behaviours (Ji et al., 2019)) are not significantly different according to gender. For future studies, we recommend researching the perception of passengers. This is to explore whether there is a meaningful differentiation according to gender regarding flight attendants' safety behaviour and conducting a safe flight operation.

\section{REFERENCES}

AASE, Karina, SKJERVE, Ann Britt and ROSNESS, Ragnar (2005), "Why Good Luck Has A Reason: Mindful Practices in Offshore Oil and Gas Drilling", Proceedings of the 6th International Conference on Organizational Learning and Knowledge: The Passion for Learning and Knowing (Ed. S. Gherardi, D. Nicolini), University of Trento E-Books, Trento, ss.193-210.

AIR ACCIDENTS INVESTIGATION BRANCH (1990), Report on the Accident to Boeing 737-400, Report No: 4/1990, Air Accidents Investigation Branch, East Midlands (UK).

AVIATION SAFETY NETWORK (2005), "Helios Flight 522 Accident Description", Aviation Safety Network Report, http://aviation-safety.net/database/record.php?id=20050814-0 (Access Date: 22.02.2021).

BALCI, Ali (2001), Sosyal Bilimlerde Araştırma: Yöntem, Teknik ve İlkeler, Pegem Yayınları, Ankara.

BARON, Robert (2012), “Double Trouble”, E-Article (21.05.2012), Available at https://www.abag.org.br/news/documents/Seg_Voo-Learn.pdf (Access Date: 22.02.2021).

BROWN, Losi and RANTZ, William (2010), "The Efficacy of Flight Attendant/Pilot Communication in A Post9/11 Environment: Viewed from both Sides of The Fortress Door", International Journal of Applied Aviation Studies, S.10(1), ss.227-248.

CHANG, Cheng-Ping, and CHIU, Ju-Mei (2009), “Flight Attendants' Emotional Labor And Exhaustion in The Taiwanese Airline Industry", Journal of Service Science and Management, S.2(4), ss.305-311.

CHEN, Ching-Fu and CHEN, Shu-Chuan (2014), "Investigating the Effects of Job Demands and Job Resources on Cabin Crew Safety Behaviors", Tourism Management, S.41, ss.45-52. 
CHEN, Shu-Chuan (2017), "Paternalistic Leadership And Cabin Crews' Upward Safety Communication: The Motivation of Voice Behavior", Journal of Air Transport Management, S.62, ss.44-53.

COX, Sue and COX, Tom (1991), "The Structure of Employee Attitudes to Safety: A European Example", Work \& Stress, S.5(2), ss.93-106.

FORD, Jane, HENDERSON, Robert and O'HARE, David (2013), "Barriers to Intra-Aircraft Communication and Safety: The Perspective of The Flight Attendants", The International Journal of Aviation Psychology, S.23(4), ss.368-387.

FORD, Jane, HENDERSON, Robert and O'HARE, David (2014), "The Effects of Crew Resource Management (CRM) Training on Flight Attendants' Safety Attitudes", Journal of safety research, S.48, ss.49-56.

FORD, Jane, O'HARE, David and HENDERSON, Robert (2013), "Putting the “We” into Teamwork: Effects of Priming Personal or Social Identity on Flight Attendants' Perceptions of Teamwork and Communication", Human Factors, S.55(3), ss.499-508.

GABBOTT, Mark, YELENA, Tsarenko and WAI, Hoe Mok (2011), "Emotional Intelligence as a Moderator of Coping Strategies And Service Outcomes in Circumstances of Service Failure", Journal of Service Research, S.14(2), ss.234-248.

GEREDE, Ender (2006), "Havacılık Emniyeti ve Havacılık Güvenliği Kavramları Arasındaki Illişki ve Farkların Belirlenmesine Yönelik Bir Araştırma", Yönetim Dergisi, S.17(54), ss.26-37.

GREGORICH, Steven, HELMREICH, Robert and WILHELM, John (1990), "The Structure of Cockpit Management Attitudes”, Journal of Applied Psychology, S.75(6), ss.682-690.

GÜRBÜZ, Sait ve ŞAHIN, Faruk (2018), Research Methods for Social Sciences, Seçkin Publishing, Ankara, $4^{\text {th }}$ Edition.

HELMREICH, Robert (1984), “Cockpit Management Attitudes”, Human Factors, S.26(5), ss.583-589.

HELMREICH, Robert and FOUSHEE, Clayton (1993), "Why Crew Resource Management? Empirical and Theoretical Bases of Human Factors Training in Aviation", Cockpit Resource Management (Ed. E. Wiener, B. Kanki, R. Helmreich), Academic Press, San Diego - CA, ss.3-45.

HELMREICH, Robert and FOUSHEE, Clayton (2010), "Why CRM? Empirical and Theoretical Bases of Human Factors Training”, Crew Resource Management, Academic Press, San Diego - CA, ss.3-57.

HELMREICH, Robert, MERRITT, Ashleigh and WILHELM, John (1999), “The Evolution of Crew Resource

Management Training in Commercial Aviation", International Journal of Aviation

Psychology, S.9(1), ss.19-32.

HENNING, Jaime B., CAROLYN, J. Stufft, STEPHANIE, C. Payne, MINDY, E. Bergman, MANNAN, Sam and NIR, Keren (2009), "The Influence of Individual Differences on Organizational Safety Attitudes", Safety Science, S.47(3), ss.337-345.

INTERNATIONAL CIVIL AVIATION ORGANIZATION (2014), Icao Cabin Crew Safety Training Manual, International Civil Aviation Organization Publisher, Montreal (Canada), Doc.1002 - AN/502, http://www.aviationchief.com/uploads/9/2/0/9/92098238/icao_doc_10002_-

_cabin_crew_safety_training_manual_1.pdf (Access Date: 24.11.2020).

JIMENEZ, Camilo, KASPER, Karissa, RIVERA, Javier, TALONE, Andrew and JENTSCH, Florian (2015), "Crew Resource Management (CRM) What Aviation Can Learn From the Application of CRM in Other Domains", Proceedings of the Human Factors and Ergonomics Society Annual Meeting, S.59(1), ss.946-950.

KIRKPATRICK, Donald (1976), "Evaluation of Training", Training and Development Handbook (Ed. Robert Craig, Lester Bittel), McGraw-Hill Publisher, New York, ss.1-27.

KISS, Captain De Vere Michael (2019), "Hypoxic Performance Decrements in Pilots with Undiagnosed Atherosclerosis", Unpublished Ph.D. Thesis, Human-Centered Design Institute - Florida Institute of Technology, West University Boulevard, Melbourne (USA). 
LI-HUA, Kao, MARGARET, Stewart and KAI-HUI, Lee (2009), "Using Structural Equation Modeling to Predict Cabin Safety Outcomes among Taiwanese Airlines", Transportation Research Part E: Logistics and Transportation Review, S.45(2), ss.357-365.

MANN, Henry B. and WHITNEY, Donald R. (1947), "On A Test of Whether One of Two Random Variables Is Stochastically Larger Than The Other", The Annals of Mathematical Statistics, S.18, ss.50-60.

MALHOTRA, Naresh (1996), Marketing Research: An Applied Orientation, Prentice-Hall Inc., New Jersey.

MENGENCI, Cengiz (2014), “Ekip Kaynak Yönetimi ve Sivil Havayolu Kazaları: Türkiye Örneği”, Ekonomi ve Sosyal Araştırmalar Dergisi, S.1(2), ss.44-61.

MING, Ji, BO, Liu, HONGWEI, Li, SHIYUN, Yang and YING, Li (2019), "The Effects of Safety Attitude and Safety Climate on Flight Attendants' Proactive Personality with Regard to Safety Behaviors”, Journal of Air Transport Management, S.78, ss.80-86.

MOSHANSKY, Virgil (1992), “Commission of Inquiry into the Air Ontario Accident at Dryden, Ontario, Final Report, Minister of Supply and Services, Ottawa - Ontario (Canada).

MUNOZ-MARRON, Daniel (2018), "Human Factors in Aviation: CRM (Crew Resource Management)", Papeles del Psicólogo/Psychologist Papers, S.39(3), ss.191-199.

MURPHY, Alexandra (2001), "The Flight Attendant Dilemma: An Analysis of Communication and Sensemaking During in-Flight Emergencies", Journal of Applied Communication Research, S.29(1), ss.30-53.

NACHAR, Nadim (2008), "The Mann-Whitney U: A Test For Assessing Whether Two Independent Samples Come From The Same Distribution", Tutorials in Quantitative Methods for Psychology, S.4(1), ss.1320.

ÖZEN, Yener and GÜL, Abdulkadir (2010), "Sosyal ve Eğitim Bilimleri Araştırmalarında Evren-Örneklem Sorunu”, Atatürk Üniversitesi Kazım Karabekir Eğitim Fakültesi Dergisi, S.15, ss.394-422.

PUNCH, Keith (2011), Sosyal Araştırmalara Giriş: Nicel ve Nitel Yaklaşımlar (Çev. Dursun Bayrak, Bader Arslan, Zeynep Akyüz), Siyasal Kitabevi, Ankara, 2.Bask1.

SALAS, Eduardo, BURKE, Shawn, BOWERS, Clint Alan and WILSON, Katherine (2001), "Team Training in the Skies: Does Crew Resource Management (CRM) Training Work?", Human Factors, S.43(4), ss.641674.

SKJERVE, Ann Britt (2008), "The Use of Mindful Safety Practices at Norwegian Petroleum Installations", Safety Science, S.46(6), ss.1002-1015.

STAKE, Robert (1995), The Art of Case Study Research, Sage Publisher, Thousand Oaks - CA.

TSOLAKIS, Akrivos (2006), "Helios Airways Flight HCY522 Boeing 737-31S at Grammatiko, Hellas on 14 August 2005”, Air Accident Investigation \& Aviation Safety Board Report, Hellenic Republic Ministry of Transport \& Communications, Athens - Greece.

US AIRWAYS (2000), Boeing 737-300/400 Pilot's Handbook, US Airways in House Printing, Pittsburgh PA.

YELGIN, Çetin and ERGÜN, Nalan (2020), "Job Demands Perceived by Cabin Crew in Airline Companies: A Case in Turkey", Theoretical Issues in Ergonomics Science, S.22.2 ss.200-218. 